\title{
HIV positivity may not have a negative impact on survival in Epstein-Barr virus-positive Hodgkin lymphoma: A Japanese nationwide retrospective survey
}

\author{
MIHOKO YOTSUMOTO ${ }^{1}$, YOSHIKAZU ITO ${ }^{2}$, SHOTARO HAGIWARA $^{3}$, YASUHITO TERUI ${ }^{4}$, \\ HIROKAZU NAGAI $^{5}$, YASUNORI OTA ${ }^{6}$, ATSUSHI AJISAWA ${ }^{7}$, TOMOKO UEHIRA ${ }^{8}$, \\ JUNKO TANUMA $^{9}$, KAZUMA OHYASHIKI ${ }^{2}$ and SEIJI OKADA ${ }^{10}$
}

\begin{abstract}
Departments of ${ }^{1}$ Laboratory Medicine, ${ }^{2}$ Hematology, Tokyo Medical University Hospital, Shinjuku-ku, Tokyo 160-0023; ${ }^{3}$ Department of Hematology, Tokyo Women's Medical University Hospital, Shinjuku-ku, Tokyo 162-8666; ${ }^{4}$ Department of Hematology Oncology, Cancer Institute Hospital of JFCR, Koto-ku,

Tokyo 135-8550; ${ }^{5}$ Department of Hematology, National Hospital Organization Nagoya Medical Center, Nagoya-shi, Aichi 460-0001; ${ }^{6}$ Department of Pathology, Teikyo University Hospital, Minato-ku, Tokyo 173-0003;

${ }^{7}$ Department of Infectious Diseases, Tokyo Metropolitan Toshima Hospital, Itabashi-ku, Tokyo 173-0015;

${ }^{8}$ Department of Infectious Diseases, National Hospital Organization Osaka National Hospital, Chuo-ku, Osaka 540-0006;

${ }^{9}$ AIDS Clinical Center, National Center for Global Health and Medicine, Shinjuku-ku, Tokyo 162-8655;

${ }^{10}$ Division of Hematopoiesis, Center for AIDS Research, Kumamoto University, Chuo-ku, Kumamoto 860-8556, Japan
\end{abstract}

Received December 29, 2017; Accepted May 24, 2018

DOI: $10.3892 / 01.2018 .9132$

\begin{abstract}
There has been no comparative clinical study focused on differences in the clinical features of Epstein-Barr virus $(\mathrm{EBV})^{+}$Hodgkin lymphoma (HL) between HIV-positive and -negative cases. In a nationwide survey from 511 institutions in Japan, the present study investigated $16 \mathrm{EBV}+$ HIV $^{\text {positive }}$ HL patients. To further clarify their characteristics in comparison with EBV+ HIV ${ }^{\text {negative }} \mathrm{HL}(\mathrm{n}=34)$ in the combination antiretroviral therapy era in Japan, the present study was performed. Results indicated that $\mathrm{EBV}^{+} \mathrm{HIV}^{\text {positive }}$ HL frequently occurred in a younger population compared with $\mathrm{EBV}^{+} \mathrm{HIV}^{\text {negative }} \mathrm{HL}(\mathrm{P}=0.0295)$, and that the $\mathrm{EBV}^{+}$ HIV $^{\text {positive }}$ HL group was not associated with the nodular sclerosis subtype in the population who were below the age of 40. Notably, the $\mathrm{EBV}^{+} \mathrm{HIV}^{\text {positive }} \mathrm{HL}$ group had a significantly higher frequency of extra-nodal involvement $(\mathrm{P}=0.0214)$, including marrow invasion. In the advanced stage, $80 \%$ of those with $\mathrm{EBV}^{+} \mathrm{HIV}^{\text {positive }} \mathrm{HL}$ did not require dose-reduction and in the majority of cases, chemotherapy was completed. There were no significant differences in the complete remission rate $(P=0.1961)$, overall survival $(P=0.200)$ and
\end{abstract}

Correspondence to: Dr Mihoko Yotsumoto, Department of Laboratory Medicine, Tokyo Medical University Hospital, 6-7-1 Nishishinjuku, Shinjuku-ku, Tokyo 160-0023, Japan

E-mail: mhk@tokyo-med.ac.jp

Key words: EBV, AIDS, HIV, Hodgkin lymphoma, prognosis progression-free survival $(\mathrm{P}=0.245)$ between $\mathrm{EBV}^{+} \mathrm{HIV}^{\text {positive }}$ $\mathrm{HL}$ (median observational period, 23.5 months) and $\mathrm{EBV}^{+}$ HIV $^{\text {negative }}$ HL (median observational period, 64.5 months), suggesting that HIV positivity may not have a negative impact on the clinical outcome of $\mathrm{EBV}^{+} \mathrm{HL}$. Notably, standard chemotherapy is effective and tolerable for $\mathrm{EBV}^{+} \mathrm{HL}$, regardless of HIV infection.

\section{Introduction}

The incidence of Hodgkin lymphoma (HL) in human immunodeficiency virus (HIV)-infected individuals has been increasing across countries since the advent of combination antiretroviral therapy (cART), and HL is presently one of the most frequent non-AIDS defining malignancies (1-3). Therefore, HIV ${ }^{\text {positive }}$ HL is currently an important complication of HIV infection in the cART era.

Our previous nationwide survey in Japan demonstrated that most HIV ${ }^{\text {positive }} \mathrm{HL}$ patients are EBV-positive $\left(\mathrm{EBV}^{+}\right)$(4). Epstein-Barr virus (EBV) is considered to play a role in the pathogenesis of an HL subset $(5,6)$; however, the frequency of EBV association in HL is markedly different between HIV ${ }^{\text {positive }} \mathrm{HL}$ (80-100\%) and HIV ${ }^{\text {negative }} \mathrm{HL}$ (20-50\%) (5-8). In HIV negative cases, EBV positivity is demonstrated to have a male predominance, a high incidence of mixed cellularity classical Hodgkin lymphoma (MCCHL), and advanced clinical stages (9). The prognostic impact of EBV positivity in HL remains controversial (9-12). It has been recently reported that HIV infection has no prognostic impact on advanced-stage HL (13). However, to the best of our knowledge, there has been no comparative clinical study that focused on the differences in the clinical features of $\mathrm{EBV}^{+} \mathrm{HL}$ between HIV positive 
and negative cases. Thus, we planned an expanded survey to compare the clinical characteristics between HIV positive HL and HIV ${ }^{\text {negative }}$ HL with pathologically detectable EBV in a Japanese population.

\section{Patients and methods}

In our previous retrospective nationwide study in Japan between 1991 and 2010 from 511 institutions among all regional centers and all educational hospitals certified by the Japanese Society of Hematology $(4,14)$, there were only 19 HIV $^{\text {positive }}$ HL patients. Among them, we found 16 evaluable $\mathrm{EBV}^{+} \mathrm{HIV}^{\text {positive }} \mathrm{HL}$ patients for analysis in this study. The criteria for EBV-positivity were defined by EBER in situ hybridization and/or LMP-1 immunostaining (4). In addition, data of newly obtained $123 \mathrm{HIV}^{\text {negative }} \mathrm{HL}$ patients who visited three regional hospitals (i.e., Cancer Institute Hospital of JFCR, National Hospital Organization Nagoya Medical Center, and Tokyo Medical University) between 2001 and 2010 were used for this study. Chart reviews were performed for all identified patients (Table I). We further re-assessed the pathological diagnosis and performed additional immunostaining for EBV assessment, as defined by EBER in situ hybridization and/or LMP-1 immunostaining, and finally identified $34 \mathrm{HIV}^{\text {negative }}$ $\mathrm{EBV}^{+} \mathrm{HL}$ patients as a control. This study was approved by the Ethics Committee of Tokyo Medical University Hospital (no. 2610; February 4, 2014), Cancer Institute Hospital of JFCR, and National Hospital Organization Nagoya Medical Center.

Response was assessed according to the International Workshop Criteria for non-Hodgkin's lymphoma (15). Overall survival (OS) was defined as the interval from HL diagnosis to death from any cause. Progression-free survival (PFS) was defined as the interval from HL diagnosis and the date on which disease progresses or the date on which the patient dies from any causes. Two HIV ${ }^{\text {positive }}$ HL patients diagnosed by autopsy were excluded from prognostic analysis. International Prognostic Score (IPS) was evaluated according to a previous report (16). Treatment completion was defined as completing the induction therapy without discontinuance. Dose reduction was defined as a $10 \%$ or more reduction in the optimal dose calculated according to body surface area. One HIV ${ }^{\text {positive }}$ HL patient was being treated with doxorubicin/bleomycin/vinblastine/dacarbazine (ABVD) at the time of this study and was therefore excluded from the analysis of treatment completion and dose reduction. Two HIV ${ }^{\text {negative }} \mathrm{HL}$ patients without evaluable clinical response were excluded from the analysis of the response rate and treatment completion (Table I).

Statistical analysis. Age difference according to HIV status was assessed using the Wilcoxon signed rank test. The difference in clinical parameters according to the HIV status was assessed using the chi-square test or Fisher's exact test, when appropriate. Overall survival and PFS between groups divided by the HIV status were compared using the log-rank (Mantel-Cox) test. GraphPad Prism software (version 5c for Macintosh; GraphPad Software Inc., La Jolla, CA, USA) was used for the statistical analysis, and P-values $<0.05$ were considered to indicate a statistically significant difference.

\section{Results}

Details of EBV-positivity. Among $19 \mathrm{HIV}^{\text {positive }} \mathrm{HL}$ patients in the previous study, there were $16 \mathrm{EBV}$-positive patients (EBER and/or LMP-1 positive 16, negative 2, unknown 1). Among the newly obtained $123 \mathrm{HIV}^{\text {negative }} \mathrm{HL}$ patients, there were 34 EBV-positive patients (EBER and/or LMP-1 positive 34 , negative 43, unknown 5, not operated 42).

Characteristics of $E B V^{+} H I V^{\text {positive }}$ Hodgkin lymphoma patients. The clinicopathologic features of $50 \mathrm{EBV}^{+} \mathrm{HL}$ patients, consisting of $16 \mathrm{HIV}^{\text {positive }}$ and $34 \mathrm{HIV}^{\text {negative }}$ patients, are summarized in Table I. All HIV ${ }^{\text {positive }}$ patients, but one, had HL diagnosis in the cART era (i.e., after 1997); 14 of the $16 \mathrm{HIV}^{\text {positive }}$ patients developed HL during the HIV follow-up at 40 (median) months (range, 6-84) after HIV diagnosis, and the remaining two were initially found to have HIV infection at the time of HL diagnosis. The HIV $^{\text {positive }} \mathrm{HL}$ patients were significantly younger in terms of median age than the HIV negative $\mathrm{HL}$ patients (45 years old vs. 60.5 years old: $\mathrm{P}=0.0158)$. The median $\mathrm{CD} 4^{+}$cell count (CD4 ${ }^{+}$count) at $\mathrm{HL}$ diagnosis was $231 / \mu 1$ (range, $1-567 / \mu 1$ ) in HIV-positive cases.

The most common subtype of HL was MCCHL in the $\mathrm{EBV}^{+}$ $\mathrm{HIV}^{\text {positive }}$ group and $\mathrm{EBV}^{+} \mathrm{HIV}^{\text {negative }}$ group $(68.8 \%$ vs. $61.8 \%$, respectively). The patient's peak age of MCCHL incidence in the $\mathrm{EBV}^{+} \mathrm{HIV}^{\text {positive }}$ group was in their $30 \mathrm{~s}$, whereas that in the $\mathrm{EBV}^{+} \mathrm{HIV}^{\text {negative }}$ group was in their 60s (Fig. 1A and B). Patients in their 20s were not observed in the HIV positive group; patients in the $\mathrm{EBV}^{+} \mathrm{HIV}^{\text {negative }}$ group showed a peak incidence of nodular sclerosis classical Hodgkin lymphoma (NSCHL) in their 20s and of MCCHL in their 60s similarly to previous reports $(17,18)$ (Fig. 1A). By contrast, no case of NSCHL was encountered in the $\mathrm{EBV}^{+} \mathrm{HIV}^{\text {positive }}$ group particularly in the patients who were below their 40s (Fig. 1B).

There were no significant differences in the incidence of advanced stage between the HIV ${ }^{\text {positive }}$ group and the HIV $V^{\text {negative }}$ group $(81.3 \%$ vs. $67.6 \%$ : $\mathrm{P}=0.258)$, or in the presence of B symptom (50\% vs. $41.2 \%$ : $\mathrm{P}=0.388)$. In contrast, significantly higher incidences of extranodal involvement $(56.3 \%$ vs. $20.6 \%$ : $\mathrm{P}=0.0150)$ and $\mathrm{BM}$ involvement by itself $(47.8 \%$ vs. $2.9 \%$ : $\mathrm{P}=0.000748)$ were observed in the $\mathrm{EBV}^{+} \mathrm{HIV}^{\text {positive }}$ group (Table I).

Treatment response and survival. The complete remission (CR) rate of the HIV ${ }^{\text {positive }}$ HL patients was not significantly different from that of the HIV $\mathrm{Hegative}^{\mathrm{HL}}$ patients $(84.6 \%$ vs. 96.9\%: $\mathrm{P}=0.196$ ) (Table I). The OS of the $\mathrm{EBV}^{+} \mathrm{HIV}$ positive HL patients, including one patient under treatment, (median observational period, 23.5 months) was not significantly different from that of the $\mathrm{EBV}^{+} \mathrm{HIV}^{\text {negative }} \mathrm{HL}$ patients (median observational period, 64.5 months) (5-year OS probability: $65.1 \%$ vs. $79.0 \%$; $\mathrm{P}=0.1921$ ) (Fig. $2 \mathrm{~A}$ ). There was no significant difference in the PFS between $\mathrm{EBV}^{+} \mathrm{HIV}^{\text {positive }} \mathrm{HL}$ and $\mathrm{EBV}^{+} \mathrm{HIV}^{\text {negative }} \mathrm{HL}$ (5-year PFS probability: $66.8 \%$ vs. $78.7 \%$; $\mathrm{P}=0.2835$ ) (Fig. 2B).

The treatment completion rate of the advanced-stage patients treated with ABVD/ABVd was $90.0 \%$ in the HIV ${ }^{\text {positive }}$ HL patients and $75.0 \%$ in the HIV $\mathrm{V}^{\text {negative }} \mathrm{HL}$ patients $(\mathrm{P}=0.326)$ (Table I). The rate of the patients with ABVD/ABVd dose 
Table I. Baseline characteristics of EBV+ HL patients with and without HIV.

\begin{tabular}{|c|c|c|c|}
\hline Variable & $\begin{array}{c}\mathrm{EBV}^{+} \mathrm{HIV}^{\text {positive }} \\
\mathrm{HL}(\mathrm{n}=16)\end{array}$ & $\begin{array}{c}\mathrm{EBV}^{+} \mathrm{HIV}^{\text {negative }} \\
\mathrm{HL}(\mathrm{n}=34)\end{array}$ & P-value \\
\hline Male/female & $14 / 2$ & $25 / 9$ & $0.232^{\mathrm{A}}$ \\
\hline Median age, years (range) & $45(31-66)$ & $60.5(20-85)$ & $0.0158^{\mathrm{B}}$ \\
\hline Absolute $\mathrm{CD} 4^{+}$cell count, cells $\times 10^{9} / 1$ (range) & $231(1-567)$ & ND & \\
\hline Viral load $<500$ copies $/ \mathrm{ml}$ & $10 / 14^{\mathrm{a}}$ & ND & \\
\hline On ART & $13 / 16(81.3 \%)$ & $0 / 34$ & \\
\hline \multicolumn{4}{|l|}{ Histological subtype $\mathrm{n}(\%)$} \\
\hline NSCHL & $3(18.8 \%)$ & $8(23.5 \%)$ & \\
\hline MCCHL & $11(68.8 \%)^{\mathrm{b}}$ & $21(61.8 \%)$ & $0.631^{\mathrm{C}}$ \\
\hline LRCHL & $0(0 \%)$ & $5(14.7 \%)$ & \\
\hline LDCHL & $1(6.3 \%)^{\mathrm{c}}$ & $0(0 \%)$ & \\
\hline Non-specific & $1(6.3 \%)$ & $0(0 \%)$ & \\
\hline \multicolumn{4}{|l|}{ Ann Arbor stage n $(\%)$} \\
\hline Localized stage & $3(18.8 \%)$ & $11(32.4 \%)$ & $0.258^{\mathrm{A}}$ \\
\hline Advanced stage & $13(81.3 \%)^{\mathrm{d}}$ & $23(67.6 \%)$ & \\
\hline Symptoms in category B of Ann Arbor staging ${ }^{\mathrm{D}}$ & $8(50.0 \%)^{\mathrm{e}}$ & $14(41.2 \%)$ & $0.388^{\mathrm{A}}$ \\
\hline Extranodal lesion & $9(56.3 \%)^{\mathrm{f}}$ & $7(20.6 \%)$ & $0.015^{\mathrm{A}}$ \\
\hline Bone marrow involvement & $7 / 16(47.8 \%)^{\mathrm{g}}$ & $1(2.9 \%)$ & $0.000748^{A}$ \\
\hline \multicolumn{4}{|l|}{ IPS } \\
\hline $0-2$ & $7(43.8 \%)$ & $16(47.1 \%)$ & $0.498^{\mathrm{A}}$ \\
\hline$\geq 3$ & $9(56.3 \%)^{\mathrm{h}}$ & $17(50.0 \%)$ & \\
\hline Unknown & & $1(2.9 \%)$ & \\
\hline \multicolumn{4}{|l|}{ Treatment } \\
\hline \multicolumn{4}{|l|}{ Localized stage } \\
\hline ABVD & 0 & 4 & \\
\hline RT & 1 & 1 & \\
\hline $\mathrm{ABVD}+\mathrm{RT}$ & 2 & 6 & \\
\hline \multicolumn{4}{|l|}{ Advanced stage } \\
\hline $\mathrm{ABVD} / \mathrm{ABVd}$ & 11 & 20 & \\
\hline $\mathrm{ABVD}+\mathrm{RT}$ & 0 & 1 & \\
\hline C-MOPP & 0 & 1 & \\
\hline $\mathrm{BD}^{\mathrm{i}}$ & 0 & 1 & \\
\hline No treatment ${ }^{\mathrm{j}}$ & 2 & 0 & \\
\hline Complete remission rate & $11 / 13(84.6 \%)^{\mathrm{k}}$ & $31 / 32(96.9 \%)$ & $0.196^{\mathrm{A}}$ \\
\hline Treatment completion rate (advanced stage) & $9 / 10(90 \%)^{1}$ & $15 / 20(75.0 \%)$ & $0.326^{\mathrm{A}}$ \\
\hline Rate of patients with $\mathrm{ABVD} / \mathrm{ABV} d$ dose reduction & $2 / 10^{\mathrm{m}}$ & $0 / 20$ & $0.103^{\mathrm{A}}$ \\
\hline Auto PBSCT & 0 & 1 & \\
\hline
\end{tabular}

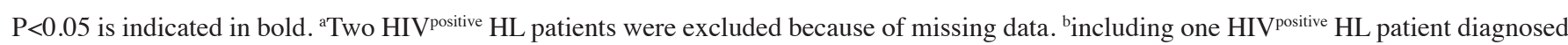
by autopsy. ${ }^{\text {cincluding one HIV }}{ }^{\text {positive }} \mathrm{HL}$ patient diagnosed by autopsy. ${ }^{\mathrm{d}}$ Two HIV ${ }^{\text {positive }} \mathrm{HL}$ patients diagnosed by autopsy were in the advanced stage. ${ }^{\text {e}}$ Two HIV ${ }^{\text {positive }}$ HL patients diagnosed by autopsy had symptoms. ${ }^{\text {TTwo HIV positive }}$ HL patients diagnosed by autopsy had extranodal lesion. ${ }^{g}$ Two HIV positive $\mathrm{HL}$ patients diagnosed by autopsy had bone marrow involvement. ${ }^{\text {h}}$ Two HIV ${ }^{\text {positive }}$ HL patients diagnosed by autopsy were IPS $\geqq 3$. 'The patient received only bleomycin and dacarbazine according to patient's request. 'ंwwo HIV positive HL patients diagnosed by autopsy received no treatment. ${ }^{\mathrm{k}}$ Two HIV ${ }^{\text {positive }}$ HL patients diagnosed by autopsy and one HIV ${ }^{\text {positive }}$ HL patient on treatment were excluded from the analysis of complete remission rate. ${ }^{1, \mathrm{~m}}$ Among 13 advanced stage HIV ${ }^{\text {positive }}$ HL patients, two patients diagnosed by autopsy and one patient on treatment were excluded from the analysis of response rate, treatment completion, and rate of patients with ABVD/ABVd dose reduction. . ${ }^{\mathrm{A}}$ Fisher's exact test; ${ }^{\mathrm{B}}$ Wilcoxon signed rank test; ${ }^{\mathrm{C}} \mathrm{Chi}$-square test; ${ }^{\mathrm{D}}$ fever, night sweats and body weight loss. ART, antiretroviral therapy; NSCHL, nodular sclerosis classical Hodgkin lymphoma; MCCHL, mixed cellularity classical Hodgkin lymphoma; LRCHL, lymphocyte-rich classical Hodgkin lymphoma; LDCHL, lymphocyte-depleted classical Hodgkin lymphoma; IPS, International Prognostic Score; ABVD, doxorubicin/bleomycin/vinblastine/dacarbazine; RT, radiotherapy; ABVd, ABVD therapy with a lower dose of dacarbazine $\left(250 \mathrm{mg} / \mathrm{m}^{2}\right)$; C-MOPP, cyclophosphamide, vincristine, procarbazine, prednisone; auto PBSCT, autologous peripheral blood stem cell transplantation. 

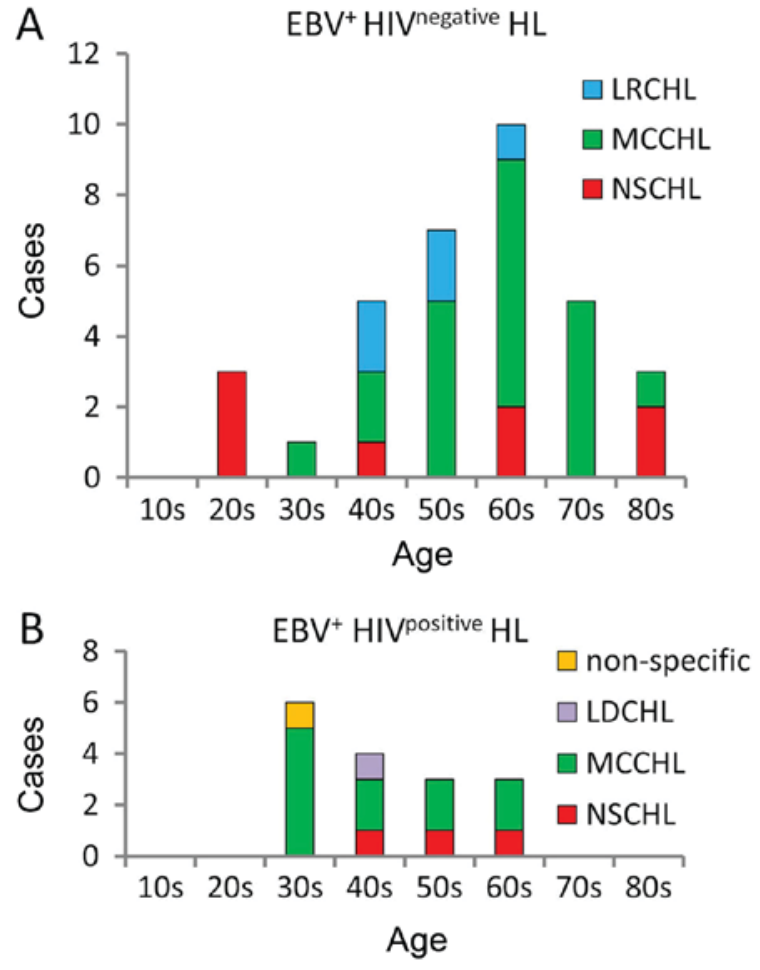

Figure 1. (A) Frequency of the pathological subtype of $\mathrm{EBV}^{+} \mathrm{HIV}^{\text {negative }}$ Hodgkin lymphoma (HL) according to age. The peaks of HL incidence were observed in the patients who were in their 20s (NSCHL) and 60s (MCCHL) in the $\mathrm{EBV}^{+} \mathrm{HIV}^{\text {negative }} \mathrm{HL}$ patients. (B) Frequency of the pathological subtype of $\mathrm{EBV}^{+} \mathrm{HIV}^{\text {positive }} \mathrm{HL}$ according to age. There was no case of NSCHL in the patients who were in their $20 \mathrm{~s}$, and the peak incidence of MCCHL was observed in the patients who were in their 30 s in the $\mathrm{EBV}^{+} \mathrm{HIV}^{\text {positive }}$ HL patients. LDCHL, lymphocyte-depleted classical Hodgkin lymphoma; LRCHL, lymphocyte-rich classical Hodgkin lymphoma; MCCHL, mixed cellularity classical Hodgkin lymphoma; NSCHL, nodular sclerosis classical Hodgkin lymphoma.

reduction was $2 / 10$ in the $\mathrm{HIV}^{\text {positive }} \mathrm{HL}$ patients and $0 / 20$ in the HIV ${ }^{\text {negative }} \mathrm{HL}$ patients $(\mathrm{P}=0.103)$. Three of the $11 \mathrm{HIV}^{\text {positive }}$ HL patients who received ABVD/ABVd in the advanced stage expired due to disease progression.

The CR rate of the advanced-stage HIV ${ }^{\text {positive }}$ HL patients treated with ABVD/ABVd was $80.0 \%$ (8/10), whereas that of the HIV ${ }^{\text {negative }} \mathrm{HL}$ patients treated with ABVD/ABVd was 94.7\% (18/19). Among the advanced-stage patients treated with $\mathrm{ABVD} / \mathrm{ABVd}$, the 5-year OS rate of the $\mathrm{EBV}^{+} \mathrm{HIV}^{\text {positive }}$ HL patients was not significantly different from that of the $\mathrm{EBV}^{+} \mathrm{HIV}^{\text {negative }} \mathrm{HL}$ patients (56.6\% vs. $75.0 \%$; $\left.\mathrm{P}=0.2063\right)$, as well as the 5-year PFS rate $(57.3 \%$ vs. $73.7 \% ; \mathrm{P}=0.2636)$. Of the $30 \mathrm{EBV}^{+}$advanced-stage HL patients, no significant difference in OS was found in the low IPS group (0-2) $(\mathrm{P}=0.696)$ or high IPS $(\geq 3)$ group $(\mathrm{P}=0.177)$ by the log-rank test (data not shown).

\section{Discussion}

EBV infection is associated with an increased risk of EBV-positive HL. EBV may play a role in the pathogenesis of EBV-positive HL $(5,6)$, but this aspect has not yet been fully clarified. There have been comparisons between HL with EBV positive and negative patients. A recent report by Koh et al describes the impact of EBV-positivity on HL in Korea (12).
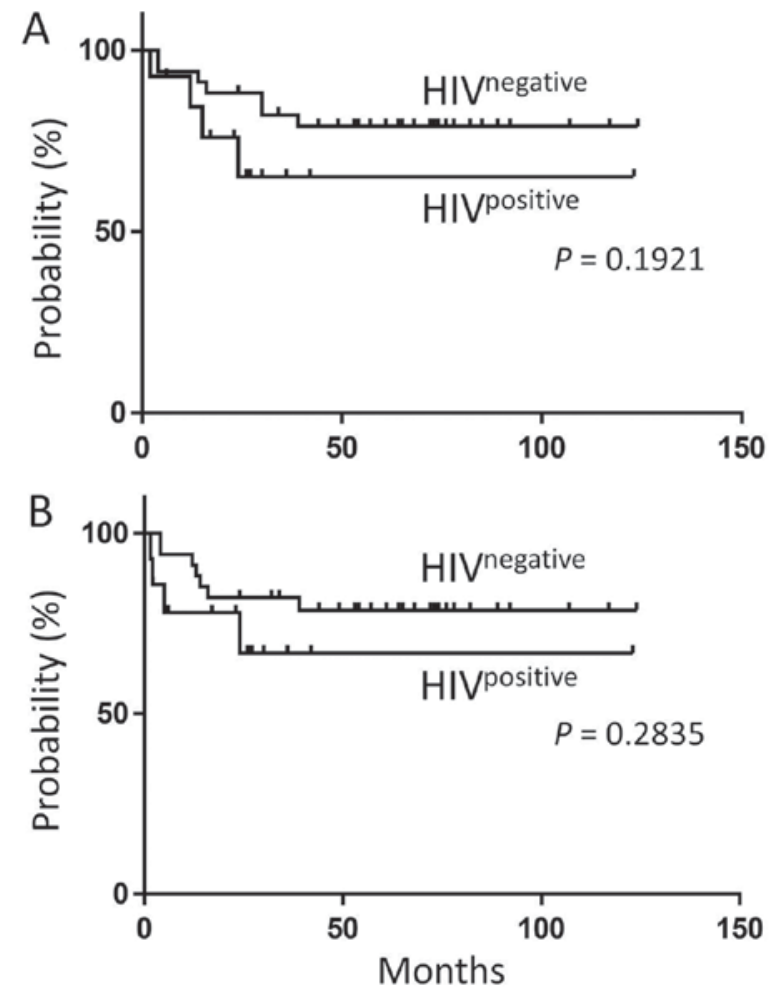

Figure 2. (A) Overall survival of $\mathrm{EBV}^{+} \mathrm{HIV}^{\text {positive }}$ and $\mathrm{HIV}^{\text {negative }} \mathrm{HL}$ patients. The OS probability of the $\mathrm{EBV}^{+} \mathrm{HIV}^{\text {positive }} \mathrm{HL}$ patients $(\mathrm{n}=14)$ was comparable to that of the $\mathrm{EBV}^{+} \mathrm{HIV}^{\text {negative }} \mathrm{HL}$ patients $(\mathrm{n}=34)(\mathrm{P}=0.1921$, log-rank test). Two HIV $^{\text {positive }}$ HL patients diagnosed by autopsy were excluded from the prognostic analysis. (B) Progression-free survival (PFS) of $\mathrm{EBV}^{+} \mathrm{HIV}^{\text {positive }}$ and $\mathrm{EBV}^{+}$ $\mathrm{HIV}^{\text {negative }} \mathrm{HL}$ patients. The PFS of the $\mathrm{EBV}^{+} \mathrm{HIV}^{\text {positive }} \mathrm{HL}$ patients $(\mathrm{n}=34)$ was comparable to that of the $\mathrm{EBV}^{+} \mathrm{HIV}^{\text {negative }} \mathrm{HL}$ patients $(\mathrm{n}=14)(\mathrm{P}=0.2835$, log-rank test). Two HIV ${ }^{\text {positive }}$ HL patients diagnosed by autopsy were excluded from the prognostic analysis.

There have also been comparisons between HIV positive HL and HIV negative HL. However, there have been no comparison data on EBV-positive HL between HIV positive and negative patients. To find out the difference, we matched the condition of EBV-positivity and made a comparison between the HIV positive and negative groups. As EBV-positive HL and EBV-negative HL act differently, it is essential to divide EBV-positive HL from EBV-negative HL to elucidate the facts about the impact of HIV infection.

The frequency of HL in HIV-infected individuals has increased two-folds in the cART era (19). It is known that HIV $^{\text {positive }} \mathrm{HL}$ patients have distinct clinicopathological features such as a high rate of EBV positivity, advanced-stage disease (20-22), and unfavorable histological subtypes, including MCCHL and lymphocyte-depleted classical HL (4). On the other hand, MCCHL is more likely to be EBV-positive across all age groups, particularly in young adults (23). In the current study, the peak age of the patients at $\mathrm{EBV}^{+} \mathrm{HIV}^{\text {positive }} \mathrm{HL}$ diagnosis was during their 30s; this age distribution was quite different from that observed in general HL showing biphasic peaks. Notably, we never found NSCHL in the patients who were below their 40s in the $\mathrm{EBV}^{+} \mathrm{HIV}^{\text {positive }} \mathrm{HL}$ group, whereas NSCHL was generally found in younger HL patients likely in the $\mathrm{EBV}^{+} \mathrm{HIV}^{\text {negative }} \mathrm{HL}$ group (Fig. 1A and B). This dissociation of pathological subtypes in the young generation in HL regarding HIV ${ }^{\text {positive }} \mathrm{HL}$, particularly for NSCHL, should be 
confirmed in other ethnic cohorts as EBV-positive lymphoma is frequently encountered in Asia.

We included two patients diagnosed by autopsy, since the data of diagnosis and stage did not affect the clinical results, including outcome (Table I). They were excluded from prognostic analysis.

We found that $\mathrm{EBV}^{+} \mathrm{HIV}^{\text {positive }} \mathrm{HL}$ showed a high frequency of extranodal involvement compared with $\mathrm{EBV}^{+} \mathrm{HIV}^{\text {negative }} \mathrm{HL}$, in accordance with previous studies (20-22). In particular, BM involvement was notable (47.8\%) in HIV-positive patients. Ann Arbor staging $(\mathrm{P}=0.5012)$ or IPS $(\mathrm{P}=0.7489)$ was not significantly different whether the condition was HIV-positive or not, and the response to therapy was comparative.

We cannot simply conclude that the comparative clinical outcome between $\mathrm{EBV}^{+} \mathrm{HIV}^{\text {positive }} \mathrm{HL}$ and $\mathrm{EBV}^{+} \mathrm{HIV}^{\text {negative }}$ $\mathrm{HL}$ in this survey is linked to the different aged populations with different pathological subtypes. Nevertheless, even with the high frequency of $\mathrm{BM}$ involvement in $\mathrm{EBV}^{+} \mathrm{HIV}^{\text {positive }}$ $\mathrm{HL}$, there were no significant differences in the $\mathrm{CR}$ rate, $\mathrm{OS}$ probability, and PFS compared with $\mathrm{EBV}^{+} \mathrm{HIV}^{\text {negative }} \mathrm{HL}$. The current study demonstrated that the standard chemotherapy for $\mathrm{EBV}^{+} \mathrm{HIV}^{\text {negative }} \mathrm{HL}$ was acceptable for $\mathrm{EBV}^{+} \mathrm{HIV}^{\text {positive }} \mathrm{HL}$ in the cART era, and we obtained almost even results in response to chemotherapy as well as outcome between these two groups. These results further suggest that Ann Arbor staging or IPS might be helpful for planning therapeutic strategies for $\mathrm{HL}$ patients, including $\mathrm{EBV}^{+} \mathrm{HIV}^{\text {positive }} \mathrm{HL}$ patients.

Introduction of new agents such as brentuximab vedotin for CD30 blockade or nivolumab for programmed death (PD)-1 blockade (24) for relapsed HL patients, and their combination with hematopoietic stem cell transplantation for younger patients are currently major topics. PD-1 is a regulator of the survival of virus-specific CD8 ${ }^{+} \mathrm{T}$ cells in HIV infection (25), and it also plays a wide role in HIV pathogenesis (26). Thus, PD-1 has emerged as an attractive potential therapeutic target. The clinical effects of humanized monoclonal antibodies for $\mathrm{PD}-1$, including nivolumab, for $\mathrm{EBV}^{+} \mathrm{HIV}^{\text {positive }} \mathrm{HL}$ are still unknown. Therefore, we should pay more attention to the outcome of $\mathrm{EBV}^{+} \mathrm{HIV}^{\text {positive }} \mathrm{HL}$ when treated with new agents. As most $\mathrm{EBV}^{+} \mathrm{HIV}^{\text {positive }} \mathrm{HL}$ patients are younger than 60 years, and more than $60 \%$ of them show MCCHL, the therapeutic strategy for such patients is an important issue to resolve.

The limitations of this study include the retrospective nature of the analysis among different institutions and terms. Although we performed a nationwide survey in Japan, the number of patients is still small because of the low incidence of HL in Japan [5\% of malignant lymphoma (27)]. Nevertheless, there have been apparently no data available regarding $\mathrm{EBV}^{+}$ HL patients with comparison based on the HIV status.

In conclusion, we found that $\mathrm{EBV}^{+} \mathrm{HIV}^{\text {positive }} \mathrm{HL}$ preferentially occurred in a younger population with no NSCHL, particularly in patients aged less than 40 years. In patients with the advanced stage of $\mathrm{EBV}^{+} \mathrm{HIV}^{\text {positive }} \mathrm{HL}, 80 \%$ of them did not require dose-reduction and most of them completed chemotherapy. Standard chemotherapy is effective and tolerable for $\mathrm{EBV}^{+} \mathrm{HL}$, regardless of HIV infection.

HIV positivity may not have a negative impact on the outcome in Japanese $\mathrm{EBV}^{+} \mathrm{HL}$. Thus, further evaluation of different ethnic cohorts is needed to provide additional information for delineating $\mathrm{EBV}^{+} \mathrm{HIV}^{\text {positive }} \mathrm{HL}$ in the cART era.

\section{Acknowledgements}

The authors would like to thank Dr Isomura at the Institute of Medical Science of Tokyo Medical University for his suggestions in the statistical analysis. The authors also would like to thank Dr Edward Barroga (http://orcid.org/0000-0002-8920-2607), Associate Professor and Senior Medical Editor from the Department of International Medical Communications of Tokyo Medical University for reviewing and editing the manuscript.

\section{Funding}

This work was supported by the ResearchProgramonHIV/AIDS (grant nos. 16fk0410108h0001 and 15Afk0410004h0003) from the Japan Agency for Medical Research and Development (AMED).

\section{Availability of data and materials}

The datasets used and analyzed during the current study are available from the corresponding author on reasonable request.

\section{Author's contributions}

MY, YI, and KO analyzed and interpreted the patient data and were major contributors in writing the manuscript. SH contributed to the nationwide data collection of HIV-positive patients. YT and HN contributed for data collection of HIV-negative patients. YO contributed to the pathological examination. SO contributed to designing the study. AA, TU and JT contributed for offering data from their affiliations.

\section{Ethics approval and consent to participate}

This study was conducted in accordance with the Declaration of Helsinki and local ethical legislation. This study was approved by the Ethics Committee of Tokyo Medical University Hospital (no. 2610; February 4, 2014), Cancer Institute Hospital of JFCR, and National Hospital Organization Nagoya Medical Center. Instead of obtaining informed consent from each patient, participants were given the opportunity to opt-out.

\section{Consent for publication}

Not applicable.

\section{Competing interests}

MY declare that they have no competing interests. NH received grants and personal fees from Chugai Pharmaceutical Co., grants and personal fees from Mundi Pharma, grants from Janssen Pharmaceutical K.K, Celgene Corporation, Bayer Yakuhin Ltd., Abbvie G.K., Takeda Pharmaceutical Co., Ltd., Bristol-Myers Squibb, and personal fees from Sanofi K.K and Esai Co., Ltd. outside the submitted work. KO received grants from Toyama Kagaku K.K., Nippon Shinyaku K.K., Pfizer, Bristol-Myers Squibb, Alexion Pharma K.K., Taiho Yakuhin, Asahikasei, Chugai Pharma K.K., and Jansen Pharma K.K, and personal fees from Celegen K.K., Novartis Pharma K.K., and Dainippon-Sumitomo Pharma outside the submitted work. 


\section{References}

1. Brugnaro P, Morelli E, Cattelan F, Petrucci A, Panese S, Eseme F, Cavinato F, Barelli A and Raise E: Non-acquired immunodeficiency syndrome defining malignancies among human immunodeficiency virus-positive subjects: Epidemiology and outcome after two decades of HAART era. World J Virol 4: 209-218, 2015.

2. Robbins HA, Pfeiffer RM, Shiels MS, Li J, Hall HI and Engels EA: Excess cancers among HIV-infected people in the United States. J Natl Cancer Inst 107: dju503, 2015.

3. Rubinstein PG, Aboulafia DM and Zloza A: Malignancies in HIV/AIDS: From epidemiology to therapeutic challenges. AIDS 28: 453-465, 2014

4. Yotsumoto M, Hagiwara S, Ajisawa A, Tanuma J, Uehira T, Nagai H, Fujikawa Y, Maeda S, Kitano K, Arima N, et al: Clinical characteristics of human immunodeficiency virus-associated Hodgkin lymphoma patients in Japan. Int J Hematol 96: 247-253, 2012.

5. Said JW: Immunodeficiency-related Hodgkin lymphoma and its mimics. Adv Anat Pathol 14: 189-194, 2007.

6. Flavell KJ and Murray PG: Hodgkin's disease and the Epstein-Barr virus. Mol Pathol 53: 262-269, 2000.

7. Dolcetti R, Boiocchi M, Gloghini A and Carbone A: Pathogenetic and histogenetic features of HIV-associated Hodgkin's disease. Eur J Cancer 37: 1276-1287, 2001.

8. Carbone A, Gloghini A, Serraino D and Spina M: HIV-associated Hodgkin lymphoma. Curr Opin HIV AIDS 4: 3-10, 2009.

9. Lee JH, Kim Y, Choi JW and Kim YS: Prevalence and prognostic significance of Epstein-Barr virus infection an classical Hodgkin's lymphoma: A meta-analysis. Arch Med Res 45: 417-431, 2014

10. Keegan TH, Glaser SL, Clarke CA, Gulley ML, Craig FE, Digiuseppe JA, Dorfman RF, Mann RB and Ambinder RF: Epstein-Barr virus as a marker of survival after Hodgkin's lymphoma: A population-based study. J Clin Oncol 23: 7604-7613, 2005.

11. Jarret RF, Stark GL, White J, Angus B, Alexander FE, Krajewski AS, Freeland J, Taylor GM and Taylor PR; Scotland and Newcastle Epidemiology of Hodgkin Disease Study Group: Scotland and newcastle epidemiology of hodgkin disease study group. Impact of tumor Epstein-Barr virus status on presenting features and outcome in age-defined subgroups of patients with classic Hodgkin lymphoma: A population-based study. Blood 106: 2444-2451, 2005.

12. Koh YW, Yoon DH, Suh C and Huh J: Impact of the Epstein-Barr virus positivity on Hodgkin's lymphoma in a large cohort from a single institute in Korea. Ann Hematol 9: 1403-1412, 2012.

13. Sorigué M, García O, Tapia G, Baptista MJ, Moreno M, Mate JL, Sancho JM, Feliu E, Ribera JM and Navarro JT: HIV-infection has no prognostic impact on advanced-stage Hodgkin lymphoma. AIDS 31: 1445-1449, 2017.

14. Hagiwara S, Yotsumoto M, Odawara T, Ajisawa A, Uehira T, Nagai H, Tanuma J and Okada S: Non-AIDS-defining hematological malignancies in HIV-infected patients: An epidemiological study in Japan. AIDS 27: 279-283, 2013.
15. Cheson BD, Horning SJ, Coiffer B, Shipp MA, Fisher RI, Connors JM, Lister TA, Vose J, Grillo-López A, Hagenbeek A, et al: Report of an international workshop to standardize response criteria for non-Hodgkin's lymphomas. NCI Sponsored International Working Group. J Clin Oncol 17: 1244, 1999.

16. Hasenclever D and Diehl V: A prognostic score for advanced Hodgkin's disease. International prognostic factors project on advanced hodgkin's disease. N Engl J Med 339: 1506-1514, 1998.

17. Morton LM, Wang SS, Devesa SS, Hartge P, Weisenburger DD and Linet MS: Lymphoma incidence patterns by WHO subtype in the United States, 1992-2001. Blood 107: 265-276, 2006.

18. Shimabukuro-Vornhagen A, Haver H, Engert A, Balleisen L, Majunke P, Heil G, Eich HT, Stein H, Diehl V and Josting A: Lymphocyte-rich classical Hodgkin's lymphoma: Clinical presentation and treatment outcome in 100 patients treated within German Hodgkin's Study Group trials. J Clin Oncol 23: 5739-3745, 2005.

19. Shiels MS, Pfeiffer RM, Gail MH, Hall HI, Li J, Chaturvedi AK, Bhatia K, Uldrick TS, Yarchoan R, Goedert JJ and Engels EA: Cancer burden in the HIV-infected population in the United States. J Natl Cancer Inst 103: 753-762, 2011.

20. Hoffman C, Chow KU, Wolf E, Faetkenheuer G, Stellbrink HJ, van Lunzen J, Jaeger H, Stoehr A, Plettenberg A, Wasmuth JC, et al: Strong impact of highly active antiretroviral therapy on survival in patients with human immunodeficiency virus-associated Hodgkin's disease. Br J Haematol 125: 455-462, 2004.

21. Nguyen ML, Farrell KJ and Gunthel CJ: Non-AIDS-defining malignancies in patients with HIV infection in the HAART era. Curr Infect Dis Rep 12: 46-55, 2010.

22. Spina M, Carbone A, Gloghini A, Serraino D, Berretta M and Tirelli U: Hodgkin's disease in patients with HIV infection. Adv Hematol 2011: 402682, 2011.

23. Glaser SL, Lin RJ, Stewart SL, Ambinder RF, Jarrett RF, Brousset P, Pallesen G, Gulley ML, Khan G, O'Grady J, et al: Epstein-Barr virus-associated Hodgkin's disease: Epidemiologic characteristics in international data. Int J Cancer 70: 375-382, 1997.

24. Ansell SM, Lesokhin AM, Borrello I, Halwani A, Scott EC, Gutierrez M, Schuster SJ, Millenson MM, Cattry D, Freeman GJ, et al: PD-1 blockade with nivolumab in relapsed or refractory Hodgkin's lymphoma. N Engl J Med 372: 311-319, 2015.

25. Petrovas C, Casazza JP, Brenchley JM, Price DA, Gostick E, Adams WC, Precopio ML, Schacker T, Roederer M, Douek DC and Koup RA: PD-1 is a regulator of virus-specific CD8 ${ }^{+} \mathrm{T}$ cell survival in HIV infection. J Exp Med 203: 2281-2292, 2006.

26. Porochis F and Kaufmann DE: Role of PD-1 in HIV pathogenesis and as target for therapy. Curr HIV/AIDS Rep 9: 81-90, 2012.

27. The World Health Organization classification of malignant lymphomas in Japan: Incidence of recently recognized entities. Lymphoma Study Group of Japanese Pathologists. Pathl Int 50: 696-702, 2000. 